\title{
CLINICAL PROFILE AND BACTERIOLOGICAL SPECTRUM OF NEONATAL SEPSIS, IN A TERTIARY CARE HOSPITAL, KASHMIR INDIA
}

\author{
Suhail Ahmad Naik ${ }^{1}$, Altaf Ahmad², Mohd Irshad³, Ghulam Rasool ${ }^{4}$
}

${ }^{1}$ Senior Resident, Department of Paediatrics, G. B. Pant Children Hospital GMC, Srinagar, Kashmir, India.

${ }^{2}$ Senior Resident, Department of Paediatrics, G. B. Pant Children Hospital GMC, Srinagar, Kashmir, India.

3 Senior Resident, Department of Paediatrics, G. B. Pant Children Hospital GMC, Srinagar, Kashmir, India.

${ }^{4}$ Assistant Professor, Department of Paediatrics, G. B. Pant Children Hospital GMC, Srinagar, Kashmir, India.

ABSTRACT

\section{BACKGROUND}

Neonatal sepsis is one of the commonest causes of morbidity and mortality in neonates in India compared to the developed countries. It is one of the four leading causes of morbidity and mortality in India among the neonates due to delivery and postnatal follow up in an unhealthy environment and low socio-economic state leading to maternal infection and premature delivery. It is absolutely necessary to diagnose early neonatal sepsis and its cause using clinical signs and rapid diagnostic method so that no time is wasted in starting appropriate treatment.

\section{MATERIALS AND METHODS}

A hospital-based study carried out in the Department of Neonatology over the period from 15 June 2013 to 15 May 2014 . Setting- A teaching, research and tertiary care hospital at Srinagar, Kashmir, North India.

Participants- All the neonates, in-born or out-born with at least one of the following anamnestic or clinical criteria as developed by the French National Agency for Accreditation and Health, were included in study. Procedure: Variables recorded were- presenting risk factors, symptoms, clinical signs, baseline laboratory tests, blood, urine and CSF cultures and sensitivities.

\section{RESULTS}

100 neonates were included in the study. The most common symptoms of neonatal sepsis were general (62\%) followed by respiratory (54\%). 32\% neonates were having fever and 34\% hypothermia. Klebsiella was most common gram-negative organism (36.84) grown and CONS most common gram-positive organism (13.5\%) among culture positive sepsis.

\section{CONCLUSION}

Neonatal sepsis is a major cause of morbidity and mortality in neonates in Kashmir India despite recent improvements in the health care system. Clinical manifestations are nonspecific and varied and early diagnosis is must to prevent morbidity and mortality. Gram negative neonatal sepsis is most common.

\section{KEY WORDS}

Neonatal Sepsis; LOS; EOS; Blood Culture.

HOW TO CITE THIS ARTICLE: Naik SA, Ahmad A, Irshad M, et al. Clinical profile and bacteriological spectrum of neonatal sepsis, in a tertiary care hospital, Kashmir India. J. Evolution Med. Dent. Sci. 2019;8(06):346-351, DOI: 10.14260/jemds/2019/76

\section{BACKGROUND}

Sepsis is commonest cause of neonatal mortality and is probably responsible for $30 \%$ - $50 \%$ of the neonatal death each year in developing countries. It is estimated that $20 \%$ to $30 \%$ of neonates develop sepsis and approximately $1 \%$ die of sepsis related causes. Sepsis related mortality is largely preventable with rational anti-microbial therapy and aggressive supportive care.1,2 In 2006, the World Health Organization (WHO) reported that out of the 130 million live births every year, 4 million die within the first four weeks of life. ${ }^{3}$ Of these deaths, 99\% occur in developing countries (Approximately half following difficult deliveries at home) against $1 \%$ in developed countries. ${ }^{4}$

'Financial or Other Competing Interest': None.

Submission 31-12-2018, Peer Review 25-01-2019,

Acceptance 01-02-2019, Published 11-02-2019.

Corresponding Author:

Dr. Suhail Naik,

53/54, Alfarooq Housing Colony,

Bemina, Srinagar-190015,

$J \& K$, India.

E-mail: suhailpediatrics@gmail.com

DOI: $10.14260 /$ jemds $/ 2019 / 76$

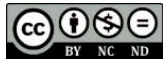

The reported incidence of neonatal sepsis is 38 per 1000 live births in Asia. The incidence is lower in western countries. ${ }^{5}$ In developing countries neonatal mortality from all causes are about 34 per 1000 live births, most of the deaths occurring in the first week, most on the first day. In contrast in developed world it is five. In Asia, neonatal mortality is 34 and in Africa it is 42 , although there are wide variations within the country and within the countries themselves. ${ }^{5}$ Early onset sepsis usually presents within first 72 hours of life. In severe cases, the neonate may be symptomatic in utero (fetal tachycardia, poor beat to beat variability) or within a few hours after birth ${ }^{1}$. It is associated with acquisition of microorganism from the mother, transplacental infection or an ascending infection from the cervix caused by organisms that colonize in the mother's genitourinary tract. The infant may acquire the microbe by passage through the colonized birth canal during delivery.1,2,6,7 Late onset sepsis usually presents after 72 hours of age. ${ }^{1}$ It is acquired from the environment. The infant's skin, respiratory tract, conjunctiva, gastrointestinal tract and umbilicus may become colonized from environment, leading to possibility of late onset sepsis from 
invasive microorganisms. Vectors for colonization include vascular or urinary catheter, indwelling lines or contact from care givers with bacterial colonization.1,2,6,7

\section{Risk Factors for Neonatal Septicaemia}

Prematurity is the single most prognostic factor in neonatal septicaemia. Premature infants have 3-10-fold higher risk compared to term babies. ${ }^{8}$ Babies with birth weight less than 2500 grams are more likely to develop septicaemia due to inappropriate immunological response. Birth weight less than 1000 grams increases the neonatal infection rate by 26 folds when compared to term infants. ${ }^{9}$ Birth asphyxia is one of the perinatal risk factors for sepsis as asphyxia depress the immune functions. Additional intervention frequent suctioning, intubation, prolonged ventilator care to manage asphyxia may impact extra risk of contracting infections in neonates and birth injuries may further complicate the issue.10,11 Male infants are 2 to 6 time more at risk of neonatal septicemia than females. ${ }^{12}$ Septicaemia is found to be more common among those infants whose mother had prolonged rupture of membrane with increased risk of contamination of amniotic fluid by organism from birth canal before delivery. ${ }^{13}$ Maternal fever in association with polymorphonuclear leucocytosis and presence of bacteriological evidence of infection has been investigated as predisposing condition for sepsis. The reported range of neonatal sepsis when chorioamnionitis is present is $3 \%$ to $20 \%{ }^{14}$

The presence of foul-smelling liquor or Meconium stained liquor has been found significant risk factor for neonatal sepsis. ${ }^{11}$ Multiple vaginal examinations $(>3$ vaginal examination after onset of labour) are associated with $20 \%$ of early onset sepsis. It is an independent risk factor in causing neonatal septicemia. ${ }^{11}$ Labour lasting for more than 24 hours with prolonged duration of second stage of labour with ruptured membranes, increases the chances of invasion of microorganisms in to the foetus. ${ }^{11}$ Abnormal presentation, difficult labour and instrumental vaginal delivery are associated with increased risk of infection. Unclean delivery practice in home deliveries and prolonged hospital stay of babies delivered by operative means predispose them to infections acquired from the environment. ${ }^{15}$

The microorganisms most commonly reported from developed world to be associated with early onset infection include GBS (40.7\%) and E. coli (17.2\%) are predominant organism others being Streptococcus viridians, Enterococci and Staphylococcus aureus. ${ }^{13,15}$

In developing countries gram negative bacilli are the predominant causative microorganisms for early onset of sepsis mainly represented by Klebsiella, E. coli and Pseudomonas. Of the gram-positive Staphylococcus aureus, CONS, Streptococcus pneumonia and Streptococcus pyogenes are common isolate. Group B Streptococcus is generally rare or not seen at al.13,16,17

\section{Clinical Signs and Symptoms}

1. General- Alteration in behaviour and change in established feeding pattern is an early sign. Lethargy, refusal to feed, feed intolerance, failure to gain weight, temperature instability (Hypothermia/ Fever).
2. Circulatory System- Pallor, cyanosis, cold clammy skin, bradycardia/ tachycardia, poor capillary filling and hypotension.

3. Respiratory System- Apnoea, dyspnoea, tachypnoea with chest retraction, cyanosis, grunting and flaring.

4. Central Nervous System- Lethargy. Irritability, high pitched cry. Blank look, hypotonia, abnormal reflexes, seizures, tremors and bulging anterior fontanel.

5. Gastrointestinal Tract- Vomiting, diarrhoea, abdominal distension hepatomegaly and splenomegaly.

6. Renal System- Oliguria.

7. Haematological System- jaundice, pallor, splenomegaly, petechiae, purpura and mucosal bleeding.

8. Skin changes- Multiple pustules, abscesses, sclerema, mottling, umbilical redness and discharge.

\section{Aim of the Study}

This study aimed to determine the clinical profile and bacteriological spectrum of neonatal sepsis.

\section{MATERIALS AND METHODS}

The descriptive study conducted in the neonatology unit of G.B Pant Pediatric Hospital and Research centre Srinagar Kashmir. The study was done from June 15 to May 2013. The study population consisted of all symptomatic neonates ( 0 to 28 days) with a maternal history suggestive of infection admitted in this unit within the study period.

\section{Inclusion Criteria}

Neonates Born to Mothers with at Least One of the following Risk Factors are Included-

a. Premature rupture of membranes (PROM) $>12$ hours.

b. More than 3 vaginal examinations after rupture of membranes.

c. Intrapartum fever $\left(>38^{\circ} \mathrm{C}\right)$.

d. Foul-smelling liquor.

e. Meconium stained liquor.

f. Maternal UTI within 2 weeks prior to delivery.

g. Prolonged and difficult delivery with instrumentation.

\section{Exclusion Criteria}

a. New born babies with gestational age $<28$ weeks.

b. Neonates with birth weight less than $<1000 \mathrm{gm}$.

c. Neonates with lethal congenital anomalies.

d. Still born and fetal deaths.

e. Post-dated neonates.

\section{Patient selection}

Patient selection was done in two phases-

- Phase 1: all the neonates, in-born or out-born with at least one of the following anamnestic or clinical criteria as developed by the French National Agency for Accreditation and Health.18

1. Anamnestic Criteria: Unexplained prematurity with gestational age $\leq 35$ weeks, prolonged rupture of membranes ( $\geq 12$ hours), stained or purulent amniotic fluid, untreated recurrent urogenital infections in the last trimester of pregnancy, maternal fever of $\geq 38^{\circ} \mathrm{C}$ during labour, delivery at home, apparently healthy twin with other symptomatic. 
2. Clinical Criteria: Fever (temperature $>38^{\circ} \mathrm{C}$ ) or hypothermia (temperature $<35^{\circ} \mathrm{C}$ ), respiratory signs (apnoea, respiratory distress), neurologic signs (Hypotonia, weak reflexes, perturbation of consciousness, convulsions, coma, irritability), digestive signs (refusal to suck, vomiting, diarrhoea), jaundice (early [ $<24$ hours after birth] or prolonged),

- Phase 2: included all neonates retained after the criteria in Phase 1. Samples for complete blood count (CBC), Creactive protein (CRP), urine, blood and cerebrospinal fluid (CSF) cultures were taken and sent to the laboratory. Chest x-rays were done on those who presented with respiratory symptoms.

The following are considered as signs and symptoms suggestive of sepsis-

\section{General}

Hypothermia, Poor feeding, Sclerema, Mottling, Lethargy.

\section{Cardiovascular System}

Bradycardia, Tachycardia, CFT $>2$ second

\section{Respiratory System}

Apnoea, RDS, Chest retractions, Cyanosis, Grunting.

\section{Central nervous System}

Hypotonia, Irritability, Seizures, High pitched cry.

\section{Gastrointestinal System}

Vomiting, Abdominal distension, Hepatomegaly.

All the neonates meeting the inclusion criteria were included in our study. Informed oral and written consent were taken from the parents.

The blood samples from neonates born to mothers with risk factors for neonatal sepsis was collected and sent for analysis. Detailed birth events. Apgar score, sex of the baby, weight of baby was recorded on the predesigned proforma. Gestational age was assessed by using modified Ballard scoring system.

Neonates were followed up for up to 72 hours from the time of birth for the development of any symptoms and signs suggestive of neonatal sepsis and if present were recorded.

Blood samples were collected, and following tests were done-

1. Total count, absolute Neutrophil count and band cell ratio.

2. Procalcitonin levels.

3. CRP levels.

4. Blood culture and sensitivity.

For the purpose of the study, neonates will be divided in 3 groups-

\section{Definite Sepsis}

Neonate with signs and symptoms suggestive of sepsis with a positive blood culture.

\section{Probable Sepsis}

Will be based on any one of the following-

- Two or more signs suggestive of sepsis with at least one abnormal laboratory parameters.

- One or more signs suggestive of sepsis with two or more abnormal laboratory parameters.

\section{No Sepsis}

Any signs of sepsis or abnormal lab parameters.

Once samples were taken, the neonates were placed on antibiotherapy (Ampicillin or Cefotaxime, and Gentamycin). In those with positive cultures, antibiotherapy was readjusted according to sensitivity results.

\section{Data Analysis}

Data was entered in Epi Info 2000 and analysed with the Statistical Package for Social Sciences version 11.0 (SPSS 11.0) software. Descriptive statistics was used to analyse the collected data.

\section{RESULTS}

This descriptive study was conducted in Neonatal Division of Department of Paediatrics, G. B. Pant Hospital Srinagar Kashmir from June 2013 to May 2014. The blood samples from 100 babies meeting the inclusion and exclusion criteria constituted the material for study.

\begin{tabular}{|c|c|c|}
\hline Sl. No. & Age (Days) & No. of Babies \\
\hline 1 & 1 -5 Days & 73 \\
\hline 2 & $6-10$ Days & 15 \\
\hline 3 & $11-15$ Days & 8 \\
\hline 4 & $16-20$ Days & 3 \\
\hline 5 & $>21$ Days & 1 \\
\hline \multicolumn{2}{|c|}{ Table 1. Age Distribution of Babies (Days) } \\
\hline \multicolumn{2}{|c|}{} \\
\hline
\end{tabular}

\begin{tabular}{|c|c|c|}
\hline Sl. No. & Sex & No. of Babies \\
\hline 1 & Boy & 57 \\
\hline 2 & Girl & 43 \\
\hline \multicolumn{2}{|c|}{ Table 2. Shows Sex distribution of cases } \\
\hline
\end{tabular}

\begin{tabular}{|c|c|c|}
\hline Sl. No. & Birth Weight & No. of Babies \\
\hline 1 & Above $2.5 \mathrm{Kg}$ (Normal) & 34 \\
\hline 2 & $1.5 \mathrm{Kg}$ to $2.5 \mathrm{Kg}$ (LBW) & 51 \\
\hline 3 & $1 \mathrm{Kg}$ to $1.5 \mathrm{Kg}$ (VLBW) & 14 \\
\hline 4 & Below $1 \mathrm{Kg}$ (ELBW) & 1 \\
\hline & Total Cases & 100 \\
\hline
\end{tabular}

\begin{tabular}{|c|c|}
\hline Past History & Nos. (\%) \\
\hline $\begin{array}{c}\text { Unexplained Prematurity (<37 Weeks of } \\
\text { Gestation) }\end{array}$ & $59(59)$ \\
\hline Prolonged Membrane Rupture (>12 Hours) & $27(27)$ \\
\hline Maternal Fever & $21(21)$ \\
\hline Uro-Genital Infections & $2(2.0)$ \\
\hline Delivery at Home & $16(16)$ \\
\hline Meconium Stained Amniotic Fluid & $6(6.0)$ \\
\hline Foul-Smelling Amniotic Fluid & $9(9.0)$ \\
\hline $\begin{array}{c}\text { Table 4. Showing Distribution of Various Risk Factors For } \\
\text { Neonatal Sepsis and Obstetrical Past History. }\end{array}$ \\
\hline *A mother could have had more than one of the above \\
\hline
\end{tabular}




\begin{tabular}{|c|c|c|c|}
\hline $\begin{array}{l}\text { Presenting } \\
\text { Symptoms }\end{array}$ & & Frequency & $\begin{array}{l}\text { Total } \\
\text { (\%) }\end{array}$ \\
\hline Thermal & Fever & 32 & $32 \%$ \\
\hline Dysregulation & Hypothermia & 34 & $34 \%$ \\
\hline \multirow{2}{*}{$\begin{array}{l}\text { Behavioural } \\
\text { Disorders }\end{array}$} & Refusal to Suck & 31 & \multirow{2}{*}{$42(42)$} \\
\hline & Irritability & 11 & \\
\hline \multirow{2}{*}{$\begin{array}{l}\text { Respiratory } \\
\text { Disorders }\end{array}$} & Respiratory Distress & 48 & \multirow{2}{*}{$54(54 \%)$} \\
\hline & Cough & 6 & \\
\hline $\begin{array}{l}\text { Neurologic } \\
\text { Disorders }\end{array}$ & Convulsions & 16 & $16 \%$ \\
\hline \multicolumn{2}{|c|}{$\begin{array}{c}\text { GIT (Vomiting and Abdominal } \\
\text { Distension) }\end{array}$} & 46 & $46 \%$ \\
\hline \multicolumn{4}{|c|}{$\begin{array}{c}\text { Table 5. Showing Spectrum of Clinical Symptoms in Baby } \\
\text { with Sepsis. Distribution of Neonates According to } \\
\text { Presenting Symptoms }\end{array}$} \\
\hline
\end{tabular}

The most frequent clinical findings were thermal dysregulation $66 \%$ and respiratory symptoms $54 \%$ and gastrointestinal symptoms in $46 \%$ babies

\begin{tabular}{|c|c|c|}
\hline $\begin{array}{l}\text { Clinical } \\
\text { Findings }\end{array}$ & & No. (\%) \\
\hline \multirow{2}{*}{$\begin{array}{c}\text { Thermal } \\
\text { Dysregulation }\end{array}$} & Fever $(n=32)$ & \multirow{2}{*}{$66(66 \%)$} \\
\hline & Hypothermia $(\mathrm{n}=34)$ & \\
\hline \multirow{2}{*}{$\begin{array}{l}\text { Respiratory } \\
\text { Disorders }\end{array}$} & Respiratory Distress (48) & \multirow{2}{*}{$51(51 \%)$} \\
\hline & Apnoea + Lung Crackles ( $\mathrm{n}=3$ ) & \\
\hline \multirow{3}{*}{$\begin{array}{l}\text { Neurologic } \\
\text { Disorders }\end{array}$} & Hypotonia ( & \multirow{3}{*}{$21(21 \%)$} \\
\hline & Weak Primitive Reflexes (n=7) & \\
\hline & Coma $(\mathrm{n}=2)$ & \\
\hline \multirow{2}{*}{$\begin{array}{l}\text { Skin/Mucosa } \\
\text { Disorders }\end{array}$} & Jaundice $(\mathrm{n}=6)$ & \multirow{2}{*}{$7(7.0 \%)$} \\
\hline & Skin Lesi & \\
\hline Digestive & Abundant Gastric Residue $(\mathrm{n}=4)$ & \multirow{2}{*}{$7(7.0 \%)$} \\
\hline Disorders & Abdominal Distension ( $\mathrm{n}=3$ ) & \\
\hline $\begin{array}{l}\text { Hemodynamic } \\
\text { Disorders }\end{array}$ & Pallor & $6(6.0 \%)$ \\
\hline \multicolumn{3}{|c|}{$\begin{array}{l}\text { Table 6. Showing Spectrum and Distribution of Clinical } \\
\text { Signs in Babies with Neonatal Sepsis }\end{array}$} \\
\hline \multicolumn{3}{|c|}{$\begin{array}{l}{ }^{*} \text { A child could have had more than one of the above clinical } \\
\text { findings }\end{array}$} \\
\hline
\end{tabular}

\begin{tabular}{|c|c|c|}
\hline Sl. No. & Growth & No. of Baby \\
\hline 1 & No Growth & 62 \\
\hline 2 & Growth & 38 \\
\hline \multicolumn{2}{|c|}{ Total Cases } & 100 \\
\hline & Table 7. Showing Blood Culture Results \\
\hline
\end{tabular}

\begin{tabular}{|c|c|c|c|c|c|c|c|c|}
\hline & \multirow{2}{*}{ Organism } & \multicolumn{2}{|c|}{ Blood } & \multicolumn{2}{|c|}{ Urine } & \multicolumn{2}{|c|}{\begin{tabular}{|c|} 
CSF \\
\end{tabular}} & \multirow{2}{*}{$\begin{array}{c}\text { Total } \\
(\%)\end{array}$} \\
\hline & & 0-7 Days & 8-28 Days & 0-7 Days & 8-28 Days & 0-7 Days & 8-28 Days & \\
\hline & Klebsiella Spp. & 7 & 3 & 3 & 1 & - & - & $14(36.8)$ \\
\hline & E. coli & 7 & - & 3 & 2 & - & - & $12(31.5)$ \\
\hline & Pseudomonas spp. & 1 & - & 1 & & - & - & $2(5.2)$ \\
\hline $\begin{array}{c}\text { Gram Negative } \\
\text { Bacilli }\end{array}$ & Acinetobacter baumannii & 1 & 1 & - & - & - & - & $2(5.2)$ \\
\hline \multicolumn{2}{|c|}{ Total Gram-Negative Bacilli } & 16 & 4 & 7 & 3 & & & $30(79)$ \\
\hline \multirow[t]{2}{*}{$\begin{array}{c}\text { Gram Positive } \\
\text { Cocci }\end{array}$} & Staph. aureus & 2 & - & - & - & & - & $2(5.2)$ \\
\hline & CONS & 5 & - & - & - & - & - & 50 \\
\hline \multicolumn{2}{|c|}{ Total Gram-Positive Cocci } & 7 & - & - & - & - & - & $7(18.4)$ \\
\hline & Candida & 1 & & - & - & _ & $\ldots$ & $(2.6)$ \\
\hline \multicolumn{9}{|c|}{ Table 8. Showing Distribution Microorganism Grown in Blood Culture } \\
\hline
\end{tabular}

\section{DISCUSSION}

In our study we found that neonatal sepsis was more common in males than in females. The findings were consistent with studies done by Tallur et $\mathbf{a l}^{\mathbf{1 0}}$ and Mathai et al ${ }^{19}$ as shown in table 21 below.

\begin{tabular}{|c|c|c|c|c|}
\hline $\begin{array}{c}\text { SI. } \\
\text { No. }\end{array}$ & Authors & $\begin{array}{c}\text { Total No. } \\
\text { of Cases }\end{array}$ & $\begin{array}{c}\text { No. of } \\
\text { Males }\end{array}$ & $\begin{array}{c}\text { No. of } \\
\text { Females }\end{array}$ \\
\hline 1 & $\begin{array}{c}\text { Tallur } \\
\text { et al[10] }\end{array}$ & 242 & $154(63 \%)$ & $88(37 \%)$ \\
\hline 2 & $\begin{array}{c}\text { Mathai } \\
\text { et al[19] }\end{array}$ & 250 & $142(56.8 \%)$ & $108(40.7 \%)$ \\
\hline 3 & $\begin{array}{c}\text { Present } \\
\text { study }\end{array}$ & 100 & $57(57)$ & $43(43 \%)$ \\
\hline \multicolumn{5}{|c|}{ Table 9. Comparative Study Showing the Distribution of } \\
Sex in Neonatal Sepsis \\
\hline
\end{tabular}

Male babies were more than the female babies in the present study, showing a ratio of 1.3:1. The results are comparable to Mathai et $\mathrm{al}^{19}$ and closer to Tallur et al.10 Male preponderance in the neonatal septicaemia may be linked to the $x$-linked immunoregulatory gene resulting in the host's susceptibility lo the infection in males.

\begin{tabular}{|c|c|c|c|c|}
\hline $\begin{array}{c}\text { Sl. } \\
\text { No. }\end{array}$ & Authors & $\begin{array}{c}\text { Total No. } \\
\text { of Cases }\end{array}$ & $\begin{array}{c}\text { Weight } \\
<\mathbf{2 . 5} \mathbf{~ K g}\end{array}$ & $\begin{array}{c}\text { Weight } \\
\mathbf{2} . \mathbf{5 ~ K g}\end{array}$ \\
\hline 1 & Tallur et al ${ }^{10}$ & 242 & $132(54.55 \%)$ & $110(45.55 \%)$ \\
\hline 2 & Abida et al ${ }^{20}$ & 203 & $134(66 \%)$ & $69(34 \%)$ \\
\hline 3 & Present study & 100 & $66(66 \%)$ & $51(34 \%)$ \\
\hline \multicolumn{6}{|c|}{ Table 10. Comparative Study Showing the Distribution of } \\
Birth Weight in Neonatal Sepsis \\
\hline
\end{tabular}

In the present study, the higher proportion of cases were with birth weight less $2.5 \mathrm{~kg}$ was in accordance with studies like Tallur et al ${ }^{10}$ and Abida et al.20

\begin{tabular}{|c|c|c|c|c|}
\hline $\begin{array}{r}\text { SI. } \\
\text { No. }\end{array}$ & Authors & $\begin{array}{c}\text { Total No. } \\
\text { of Cases }\end{array}$ & $\begin{array}{c}\text { GA }<37 \\
\text { Weeks }\end{array}$ & $\begin{array}{c}\text { GA }>37 \\
\text { Weeks }\end{array}$ \\
\hline 1 & Raghavan et al 11 & 50 & $16(32 \%)$ & $34(68 \%)$ \\
\hline 2. & Tallur et al ${ }^{10}$ & 242 & $96(39.67 \%)$ & $146(60.33 \%)$ \\
\hline 3 & Present study & 100 & $59(59 \%)$ & $11(41 \%)$ \\
\hline
\end{tabular}

Table 11. Comparative Studies Showing the Distribution of Gestational Age with Risk Factors

In the present study the higher proportion of cases were found, with gestational age less than 37 weeks. The results of 
our study were almost comparable with Tallur et al ${ }^{10}$ and Raghavan et al.11 The higher proportions of preterm neonates compared to the term neonates in our study probably reflects difference in the population characteristics and the occurrence of the predisposing factors (Preterm incidence) among them.

In our study the most frequent symptoms were fever, behavioural disorders and respiratory symptoms. Our results were consistent with those observed by Morocco ${ }^{21}$ and Madagascar. 22

The most frequent risk factors found in our study are not different from those described by other authors. We found that the most frequent risk factors for infection were unexplained prematurity with gestational age $<37$ weeks and PROM. In other studies, the most frequent factors were foulsmelling vaginal discharge and $\mathrm{PROM}, 23$ or prematurity and cervico-vaginal infections. ${ }^{24}$ In developed countries especially in France, abnormal amniotic fluid and PROM were most frequent. ${ }^{25}$ According to the French National Agency for Accreditation and Health, ${ }^{5}$ PROM, premature gestation and perinatal maternal fever above $38^{\circ} \mathrm{C}$ are major factors in neonatal infection.

In our study the bacterial ecology was dominated by gram negative bacilli although we had only 38 neonates with positive cultures. From all the germs isolated Klebsiella spp (36.84\%), Escherichia coli $(31.5 \%)$ were the most frequent. This high prevalence of gram negative bacteria compared to gram positive has also been found in many other studies in other developing countries. $24,26,27$ The pathogens implicated in neonatal sepsis in developing countries differ from those in developed countries. Overall, Gram negative pathogens are more common and Group streptococcus, is generally rare 28 .

The fact that infection was confirmed bacteriologically in only 36 neonates is a major limitation of our study. Some of the neonates had been through other health facilities where antibiotherapy was administered before being referred to the hospital.

Early diagnosis with a reasonable degree of accuracy will help the clinician to decide on the usage of proper antibiotic which will help in reducing the morbidity and mortality.

\section{CONCLUSION}

We conclude that neonatal sepsis is a major cause of morbidity and mortality in neonates despite recent improvements in the health care system. Clinical manifestations are nonspecific and varied. Early diagnosis with a reasonable degree of accuracy will help the clinician to decide on the usage of proper antibiotic which will help in reducing the morbidity and mortality.

\section{ACKNOWLEDGMENT}

We sincerely thank the mothers of the babies who accepted to participate in this study, and the hospital authorities who permitted us to conduct the study in this institution.

\section{REFERENCES}

[1] Aggarwal R, Sarkar N, Deorari AK, et al. Sepsis in the newborn. Indian J Pediatr 2001;68(12):1143-7.

[2] Sankar MJ, Aggarwal R, Deorari AK, et al. Sepsis in the newborn. Indian J Pediatr 2008;75(3):261-6.

[3] La santé du nouveau-né quatre millions de nouveauné meurtchaqueannée, bienqu'ilexiste des interventions efficacesetpeuchères.

2006.

http://www.dcp2.org/file/92/DCPP-MDGs-

French.pdf.

[4] Labie D. Le scandale des quatre millions de mortsnéonataleschaqueannée-bilanet actions possibles. Médecine/Sciences 2005;21:768-71.

[5] Verganano S, Sharland M, Kazembe P, et al. Neonatal sepsis: an international perspective. Arch Dis Child Fetal Neonatal Ed 2005;90(3):F220-4.

[6] Remington JR, Klein JO. Infectious diseases of the fetus and newborn infants. $5^{\text {th }}$ edn. Philadelphia: WB Saunders Company 2001.

[7] Singh M. Care of the newborn. $6^{\text {th }}$ edn. Sagar Publishers 2004.

[8] National Neonatal Perinatal Database. Report 200203. NNPD Nodal Center Publisher. Department of Pediatrics. All India Institute of Medical Science. New Delhi.

[9] Gerdes JS. Diagnosis and management of bacterial infections in neonate. Pediatric Clin North Am 2004;51(4):939-59, viii-ix.

[10] Tallur SS, Kasturi AV, Nadgir SD, et al. Clinicobacteriological study of neonatal septicemia in Hubli. Indian J Pediatr 2000;67(3):169-74.

[11] Raghavan M, Mondal GP, Bhatt BV, et al. Perinatal risk factors in neonatal infections. Indian $\mathrm{J}$ Pediatr 1992;59(3):335-40.

[12] Ahmed AS, Chowdhury MA, Hoque M, et al. Clinical and bacteriological profile of neonatal septicemia in a tertiary level pediatric hospital in Bangladesh. Indian Pediatrics 2002;39(11):1034-8.

[13] Behrman RE, Kliegman RM, Jenson HB. Nelson Textbook of Pediatrics. 18th edn. Philadelphia: WB Saunders Company 2004.

[14] Gerdes JS, Polin R. Early diagnosis and treatment of neonatal sepsis. Indian J Pediatr 1998;65(1):63-78.

[15] Chiesa C, Panero A, Osborn JF, et al. Diagnosis of neonatal sepsis: a clinical and laboratory challenge. Clin Chem 2004;50(2):279-87.

[16] Kuruvilla KA, Pillai S, Jesudason M, et al. Bacterial profile of sepsis in a neonatal unit in South India. Indian Pediatr 1998;35(9):851-8.

[17] Schuchat A, Zywicki SS, Dinsmoor MJ, et al. Risk factors and opportunities for prevention of early onset Sepsis: a multicenter case-control study. Pediatrics 2000;105(1 Pt 1):21-6.

[18] Yoon HS, Shin YJ, Ki M. Risk factors for neonatal infections in full-term babies in South Korea. Yonsei Med J 2008;49(4):530-6.

[19] Mathai E, Christopher U, Mathai M, et al. Is C-reactive protein level useful in differentiating infected from uninfected neonates among those at risk of infection? Indian Pediatr 2004;41(9):895-900.

[20] Malik A, Hasani SE, Khan HM, et al. Nosocomial infections in newborns. Indian Pediatr 2001;38(1):6871.

[21] Aboussad A, Chafai S, Benomar S, et al. L'infection néonatale au Maroc. Etude prospective a propos de 100 cas. Med Mal Infect 1996;26(3):322-6.

[22] Andriamady RCL, Rasamoelisoa JM, Razanabololona, et al. Les infections bactériennesnéonatalesprécoces à 
la maternité de Befelatanana 1997-1998. Arch Inst Pasteur Madagascar 1999;65(2):86-9.

[23] Kago I, Ndayo WM, Tchokoteu PF, et al. Neonatal septicaemia and meningitis caused by gram-negative bacilli in Yaounde: clinical, bacteriological and prognostic aspects. Bull Soc Pathol Exot 1991;84(5 Pt 5):573-81.

[24] Da Silva LPA, Cavalheiro LG, Queirós F, et al. Prevalence of newborn bacterial meningitis and sepsis during the pregnancy period for public health care system participants in Salvador, Bahia, Brazil. Braz J Infect Dis 2007;11(2):272-6.

[25] Zanelli S, Gillet Y, Stamm D, et al. Méningites bactériennes du nourrisson âgé de une à huit semaines. Arch Pédiatr 2000;(Suppl 3):565-71.
[26] Movahedian AH, Mosayebi Z, Moniri R. Urinary tract infections in hospitalized newborns in Beheshti Hospital, Iran: a retrospective study. J Infect Dis Antimicrob Agents 2007;24:7-11.

[27] Zaidi AK, Thaver D, Ali SA, et al. Pathogens associated with sepsis in newborns and young infants in developing countries. Pediatr Infect Dis J 2009;28(Suppl 1):S10-S18.

[28] Darmstadt GL, Batra M, Zaidi AK. Parenteral antibiotics for the treatment of serious neonatal bacterial infections in developing country settings. Pediatr Infect Dis J 2009;28(Suppl 1):S37-S42. 